\title{
SPATIAL DEVELOPMENT AND UTILIZATION OF PUBLIC SPACES IN SURROUNDING COMMUTER LINE STATIONS
}

\author{
EVAWANI ELLISA \& RIZKY RAMADITYO \\ Department of Architecture, Faculty of Engineering, Universitas Indonesia, Indonesia
}

\begin{abstract}
The greater Jakarta metropolitan area with a population of over 30 million is supported by the four buffer cities of Bogor, Depok, Tangerang, and Bekasi, of which every day around 3.5 million of their residents commute to Jakarta (Jakarta Central Bureau of Statistic, 2016). The Commuter Line railway system, as one of the main transportation systems, connects the buffer cities and Jakarta. The National Commuter Line Company carries 960,000 persons/day and progressively attempts to increase the number of passengers by developing railway infrastructure including stations. The presence of the Commuter Line train system encourages sustainable mobility habits: people are able to access the station and catch the train instead of driving in their private vehicles, thereby reducing carbon emissions. This choice encourages an urban morphological transformation in areas surrounding the train stations. New functions, such as shops, restaurants, and parking areas emerge surrounding the train station, while the new sidewalks, bus stops, and other parts of the street furniture are poorly installed. Commuters begin to utilize the surrounding spots to support their various pedestrian activities, instead of using the station facilities, which are poorly maintained. Using the method of direct observation, this paper reveals the new arrangements of the urban elements around the various commuter stations and the behavioral tendencies of the commuters in utilizing them. The study found that the emergence of both new buildings and urban elements within the transit area supports the tendency of people to choose several new spots to do their activities. Unfortunately, these spots have emerged in an ad hoc manner and are poorly arranged without any sufficient planning. As a result, it has created chaos and messiness. The research findings concluded that the development of infrastructure around the Commuter Line Stations should be included with the rearrangement of accessible public spaces. Increasing convenience for the commuters is the critical strategy for attracting commuters away from their cars.

Keywords: behavior tendency, Commuter Line, pedestrian, sidewalk, urban form.
\end{abstract}

\section{INTRODUCTION}

Charles Montgomery stated that the psychology of mobility is a house of mirrors where what we want, what we do, and what makes us feel good are rarely the same choice [1]. "The Project for Public Spaces (2016)" summarized that good public spaces should have good accessibility to ease people's journey, should have proper facilities to accommodate people's needs, should be clean and secure, and should have a sense of liveliness to support any positive activities and interactions between the people [2].

Since entering the motor age, modern urban planners shared the same vision with the traffic engineers that cities and the lives of the people should be reconfigured for the automobile. The transportation engineers often use the word "efficient" for balancing the variety of prerequisites, such as the cost considerations, convenience, protection of environmental quality, and the protection of individual rights [3]. This effort caused the preference for creating the functional classification of roads separating from surrounding pedestrian activities, that it often arouses conflict with requirements for good public space.

In recent years, urban rejuvenation movements rose to balance the traffic speed and volume against the other goals for creating a livable urban setting with less pollution, less noise, and less stress. Many assumed the dangerous direction of the sprawling city was characterized by car domination and the growth of the suburbs. Most countries share the similar concern about transport related problems and the possible direction toward 
Environmentally Sustainable Transport (EST) [4]. In the South East Asian region, geographical differences and level of economic developments present diverse pictures of transport trend and situation. For example, while people in Singapore have well developed public transport systems, people in other Asian countries who live at the edge of the cities are not connected to the main road networks. Promoting equality in cities has become a mission in various parts of the world. Concerns for social justice include access to mobility, that developing countries in Asia require any mitigation strategy. Nevertheless, this does not mean that they must be expected to bear an equal or the proportionate share of the mitigation burden [5].

This paper discusses the process of how Jakarta has started to create a higher capacity transit system to reduce the domination of private motorized vehicles. Focusing on the Commuter Line train system, we analyzed the arrangement of urban form around the Commuter Line stations and the behavioral tendencies of the commuters in utilizing the existing urban space and elements. The findings of this research will contribute to promoting development-oriented rail transit, mainly to attain more sustainability in improving the areas around the existing rail stations in the greater Jakarta.

\section{PUBLIC TRANSPORTATION IN JAKARTA}

\subsection{The transportation system in Jakarta}

Initially known as Batavia up until 1945, Jakarta was an old colonial city, of which hybrid roads and canals were built to carry the horse-drawn carts, river and canal barges and other modes of transport. Even after the Dutch developed mechanized long-distance transportation systems, such as the railroads, the size of Batavia was sufficiently small for the people to walk to most of the places. Private transportation in the form of horseback and animal-drawn carriages was sufficient for longer distances. In the 1800's, horse-drawn streetcars began service to replace the horse-drawn carriages. Batavia started to enter the first generation of the motor age, when the Dutch built the roads to accommodate cars. In the early days, the Dutch thought that they could incorporate cars by adapting existing streets which mainly had accommodated the public trams, railways and horse-drawn carriages called sado or delman. In the beginning, major streets were developed to accommodate cars by widening the inherited routes and over canal ways.

As the city rapidly grew in 1930s, more roads expanded the radius of the Batavia. By the end of the colonial age, the internal transportation system in Batavia consisted of a network of new roads, complemented by a network of steam engine-powered streetcars. In the postcolonial age, the next episode in the evolution of transportation in Jakarta, in particular, included the replacement of electric-street cars with small vehicles called oplet and private vehicles.

Now, the Jakarta metropolitan area (so-called JABODETABEK) has grown very rapidly in more ways than one. In 1990, its population was 17 million, which increased to 28 million in 2010, i.e. an increase of 1.6 times in 20 years at an average growth rate of $2.5 \%$ per annum [6]. The population of JABODETABEK in 2018 exceeds 30 million, with a total area of 4,384 square kilometres. Jakarta is known as being among the worst metropolitan areas in arranging transport, as the urban transportation system is all most entirely automobile use and limited transport alternatives. Ditlantas Polda Metro Jaya (Traffic Agency DKI Jakarta) noted that the number of registered vehicles, including cars and motorcycles in the last five years reached 5.35\% per year, from 14.618 .313 in 2012 to 18.006 .640 in 2016 [7]. The total 
traffic volume has increased at the higher pace due to population growth, increase in vehicle ownership and economic prosperity.

With many kinds of motor vehicle modes, including two- and four-wheeled vehicles and lack of the mass rapid transportation system, the traffic violations on the streets are a common sight. Recently, the most problematic aspect is the excessive numbers of motorbikes, largely used for commuting. Motorbikes with their high maneuver ability always attempt to get to the front of the other queuing vehicles, resulting in gridlock and traffic jams even during nonpeak hours. The motorbikes and vehicles are parked on the street as well the public minivans (angkot) that stop anywhere along that route (according to the passenger's wish). This chaos often creates the localized disruption of vehicular traffic (bottle-neck). Another hindrance comes from the many angkot drivers with their infamous wait for ngetem, which means they stop for a long time on the roadside, while waiting for passengers to board. There is a lack of enforcement of traffic regulations as well as a lack of awareness and a weakness in the regulations and the imposition of fines or sanctions towards various violations in the streets.

Faced with the never-ending problems of traffic congestion, Jakarta is just beginning to turn to the public transit system as an effort to reverse the course of ongoing disarray. The goal of the Jakarta (DKI) metropolitan government is that in 2029 the public transport will become $60 \%$ of total transportation share [8]. Currently, the only rail-based transit system in Jakarta is the Commuter Line, as the mass rapid transit and light rail transit are still under construction. Founded in 1925 as Staats Spoorwegen (Dutch Colonial Railways), in 2008 PT Kereta Commuter Indonesia $(\mathrm{KCI})$ modernized the electrified commuter railway and made major improvements of station facilities and train cabins. Every day, around 960,000 commuters enjoy a comfortable ride on Commuter Line to commute from their homes to the heart city of Jakarta [9].

\subsection{Transportation and land use development}

The poor quality of transportation in Jakarta is similar to those found everywhere in other late-comer metropolitan cities in Asian countries with limited transport alternatives. This was partly due to national policies which encouraged motor vehicle ownership as well as the adoption of the Western street design standards and practices [9]. The streets are the places dominated by motor vehicles, thus, displacing pedestrians as the weaker elements. The feeling of unease and lack of safety overcomes pedestrians and walking is discouraged along with other non-motorized transport such as bicycles.

In practice, urban spatial structures in Indonesian cities are usually the unintended result of unforeseen consequences of policies and regulations that were designed without any particular spatial concerns [10]. The urgency for improving mobility often ignored the longterm visions for sustainable urban development due to the poor coordination of transport and land-use policies. The institutional frameworks are fragmented, which make cross-sector coordination extremely difficult. As in other cities in developing countries, the control of density or FAR (Floor Area Ratio) in many cities in Indonesia is not well-organized in relation to a high capacity transit service, so that adopting transit and land-use integration is very difficult $[11]$.

\subsection{Pedestrian areas and transit space}

The design procedures, based on the Western concept applied in the urban streets of Jakarta, are not compatible, since, in fact, they lacked consideration of the socio-cultural value system 
of place [12]. Asians are, in general, social individuals, whereby they usually do not go out alone and prefer to do activities together. In the social context, the street becomes the destination itself. A pedestrian may need to stop and buy food from a sidewalk vendor, rest on a bench, or chat with an acquaintance, thus, changing from moving to non-moving behavior. In this case, sidewalks function not only as a conduit for circulation and distribution of people, goods and services, but as the venue for communication.

Transit areas play a role as a place where people come to access the transit node and mobilize them to go to another place. In the transit area, walking is the main activity when people are moving from one point to another in the transit node, or to reach another transportation mode. It is necessary to be able to walk reasonably freely without being disturbed, without being pushed and without having to maneuver too much.

In the transit area, people usually stand to wait for the transportation mode, i.e. the train to arrive. Accordingly, the popular zone for standing in is found along the building facades and in the transitional zone between one space and the next, where it is possible to view both spaces at the same time to see whether the train has arrived. The sociologist Derk de Jonge mentioned this characteristic as the "edge effect" [13]. Within the zones, people select places to stand in recesses, on corners, in gateways, near the pillars, street lamps, or comparable physical supports which define the resting places on a small scale.

\section{CASE STUDIES: SURROUNDING COMMUTER LINE STATIONS}

The Commuter Line is an electric train system which connects the cities of Jakarta, Bogor, Depok, Tangerang, Bekasi and Cikarang. Bogor-Jakarta Kota is the busiest line, which $69.95 \%$ of the total passengers in the entire line (PT Commuter Indonesia, 2017). In order to conduct the study, four stations were chosen as case studies: 1) Bojong Gede Station is located in the buffer city zone, dominated by a semi-rural residential area; 2) Universitas Pancasila Station is located close to formal campus area and the commuters are mostly students; 3) Duren Kalibata Station is located in the transitional area between the buffer zone, the city and the downtown, close to formally arranged, vertical multi-family housing; and 4) Juanda Station is located in the central part of Jakarta surrounded by buildings with mixed functions.

\subsection{Methodology}

We initiated the research with an observation of the urban morphology and building functions around the stations. Guiding by the 1:1000 scale maps obtained from the Department of City Planning Jakarta Metropolitan Government, we conducted the initial survey through slowly walking down the surrounding areas of selected stations to confirm the situation depicted on the maps and experiencing the spaces. The initial survey was mainly focusing on: 1) how the pattern of the solid-void elements was established and how they created an access void in response to the existence of the station as a solid element; and 2) how the function of existing buildings around stations had the potential to develop into mixed-use buildings. Those two factors are important preconditions for the station area to become a transit center.

Detailed observations were undertaken on spots that were chosen by commuters to conduct certain activities within the station's surroundings. We observed the behavioral tendencies of the commuters in utilizing the urban elements around the transit area. Referring to Jan Gehl [14], his analyses focused on how commuters reacted to the public areas based on two aspects: 1) Protection - from various unwanted elements, especially traffic; 2) Comfort - good conditions for basic activities that people can engage in, such as walking, standing, and sitting. 
Data gathering of commuter behavior obtained in the duration between July-December 2017 through diverse methods and iterative field surveys that included participant observation, photography, video, map coding, and open interviews. We formed two pairs of field teams, each team conducted field works to observe on-ground situation and record every phenomenon encountered in the surrounding stations. Through map coding we recorded the physical survey information that required accurate locational indications. We were spotting and recording the ambulatory movement of pedestrian and other actors in the sidewalks and the surrounding stations to be identified in the base maps. For feasibility, reliability and transparency, we had an iterative field surveys by doing physical surveys, took the photographs and videos one day and then we were going back to the same place at different times of other days to do more physical surveys as well as take the photographs and videos. We interviewed pedestrian and other actors (such as street vendors) in order to examine the spatial behaviors that produced the spatial arrangements we had recorded that day before. We made triangulation and the amendment each day until we reached a point when no new type of phenomena was being formed.

\subsection{Urban morphology and building functions}

The Commuter Line stations which range from Bogor to Jakarta Kota have driven the transformation of surrounding urban configurations at the stations. Since each area experienced different stages of urbanization and development processes, every surrounding station shaped its own urban tissue and configuration of linkages as shown in Fig. 1.

\subsubsection{Bojong Gede Station}

The aerial view around Bojong Gede Station shows a low FAR (Floor Area Ratio) of urban morphology, since the premises consist of low-rise and small-scaled buildings (fine urban grain). Generally, while the area still has a clearly recognizable form, it tends to merge together into disorderly agglomerations. The haphazard spatial arrangement appears and apparently there is a lack of a clear conception of the urban layout as a whole. Only the station demonstrated as an outstanding single building. One-way streets run parallel to the station and now both streets on either side are developing into commercial strips. These strip developments constitute at a functional level the local business strip and therefore these must be regarded as the business corridors at the district level. Behind the commercial strips lie the typically local residential settlements called urban kampung. Kampungs are dense, informally planned clusters of residential dwellings arranged organically and inhabited mostly by large numbers of locals and migrants [15]. Along the commercial strip, rows of various small businesses stand side-by-side in a rather disorderly configuration. The

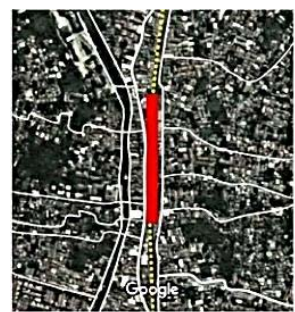

BOJONG GEDE STATION

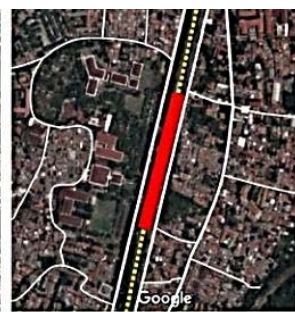

UNIV PANCASILA STATION

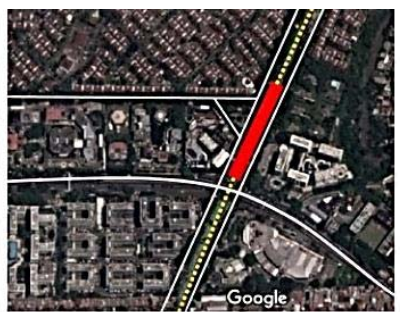

DUREN KALIBATA STATION

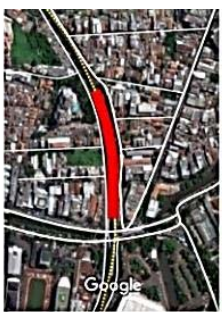

JUANDA STATION

Figure 1: Urban morphology of surrounding stations. (Source: Adapted from Google Map.) 
commercial strip consists of small canteens (warung), grocery stores, fast-food restaurants, salons, clothing shops, pet shops, and other small shops providing daily necessaries.

Most of the circulation happens on the west side within the main street in front of the station. During peak hours, motorbikes make up most of the traffic composition, as there is no attempt to segregate them from the main traffic, which is composed of private cars and para-transit vehicles, such as mini-vans (angkot). Many commuters come by motorcycle or angkot from the north or south through this street. Those who commute on motorbikes park them in the parking area next to the station or at motorbike rental parking garage before walking to the station. The rest of commuters come from the kampung area towards the station through the main corridor. Kampung alleys intersect with the main corridor to establish permeability that allows a choice of routes toward the main street.

\subsubsection{Universitas Pancasila Station}

The urban structure around Pancasila Station (Stasiun Pancasila) is dominated by the campus site of Universitas Pancasila in the West while in the East is a mixed-use, moderate density neighborhood, rented student accommodation (kos-kosan), and a handful of commercial functions. The campus took a large portion of the area consisting of a group of buildings bordered by a fence. Commercial strip development occurs on the east side with warungs, a mini-market, a laundry, photocopy services, and other shops which mostly provide for the students' needs. These shops are a response to the passing commuters as they are close to the northern side of the station's gate.

The station is flanked by two one-way arterial streets on both sides, of which one street in the west is located in front of the campus area. Generally, the commuters (mostly students) walk from the campus through the pedestrian area to the bus shelter, and then go across the street to reach the station. On the east side, a median strip with trees separates the main street with a neighborhood and provides a shady space for pedestrians walking toward the station.

Unlike Bojong Gede Station, the surrounding station is less permeable as there are not so many choices of routes to access the station. The intersection at the west side appears right in front of campus gates that connect the campus area with the pedestrian area. Since the campus has only two gates, students only have two options to access the station, which results in a long walking time. In the east side, the main intersection is located in front of the station's gate, connecting the main street with Kompos Street inside the neighborhood. The other intersections are located further south from the station's gate. Commuters prefer to choose Kompos Street as the access to the station.

\subsubsection{Duren Kalibata Station}

The urban morphology around Duren Kalibata Station is more modern and formal in character with freestanding pavilions of apartments and vertical housing blocks in Kalibata City. There are also office buildings, a shopping center, and a gated community housing for the middle and upper classes. Kalibata City was a huge public housing project converted from the formerly unproductive BATA shoe factory. Overall, the area around Duren Kalibata Station is characterized by an agglomeration of large-scale urban development with the aim to promote planned urban development to prevent unsystematic urbanization. The pattern of the large blocks creates the coarse urban grain, of which most of the buildings are rectangular solids with varieties of circular and trapezoidal forms. Each of the buildings is surrounded by its own fence, which also acts as a border to parking lots along the street. This arrangement creates introverted and segregated enclaves. The urban form in this area is predominantly vertical instead of horizontal so that each building stands as an isolated object and the spaces between them are un-formed voids. 
Considering the goal that a developed area should be opened up, urban redevelopment in the Kalibata district created the roads with an increasing reliance on automobiles. The main circulation is the flyover in the south that carried all non-local traffic. The big intersection beneath the flyover acts as the meeting point for the commuters who come from the apartments, shopping center, and offices. Although commuters only have a single route through this intersection, it does not reduce the accessibility level because the area has high visibility and a connection to the station.

\subsubsection{Juanda Station}

The Juanda district is located in the central part of Jakarta and was developed during the colonial period. Formerly known as Noordwijk Station, the station was situated in the most prominent upper-class housing district of Noordwijk and nearby important buildings, among others, including the Governor's Palace, the Schowburg (a Concert Hall), and a city park called Wilhelmina Park. Not far away from the station was the central open square of Koningsplein that became Jakarta's principal landmark, the National Monument (MONAS).

In the post-colonial age, the cityscape was restructured through redevelopment. Wilhelmina Park was transformed into the grand building of the Istiqlal Mosque, while some of the main heritage buildings still exist. Now the urban form around Juanda Station is divided into the office zone on the northeast and the southwest side. The main streets in the northern part have developed into business corridors, while the areas behind remained as high-density residential use. Commercial building in the form of shop houses and food shops dominated in the area adjacent to the station's gate.

As the area became an important business district, the streets around the station developed into arterial roads. Traffic at the main intersection, which is located near the station's gate at the south side, is always congested with all types of public and private vehicles. The Istiqlal Mosque, MONAS, and Juanda Station itself draw large of crowds of pedestrians. The smaller streets in the area behind the business corridor provide connectivity for the commuters who are coming from the residential area.

\subsection{Behavioral tendency of the commuters around the stations}

\subsubsection{Bojong Gede Station}

The streets without sidewalks around Bojong Gede station formed a busy street flanked by rows of small buildings. The absence of a designated pedestrian area means people have to walk in and around all types of vehicles to compete for circulation space. In the street, various types of motorized and non-motorized vehicles are all mixed up with pedestrians jostling for access. Combined with the poor and unruly performance of the traffic and the messy and chaotic situation of the street in front of Bojong Gede Station, this urban condition is also a typical sight of busy streets in Indonesia cities.

Although the street does not provide a comfortable place to walk, the traffic corridor becomes a "livable street." People stroll along the street lined with the small stores, as they offer the eating places, shopping venues and meeting points. For the shop customers who rode motorbikes, they park their motorbikes in front of the stores, so that pedestrians cannot walk freely and have to make maneuvers to avoid the obstructions. This has a negative impact on the walking speed of the commuters who cannot walk quickly to catch the train. A similar condition is to be found along the street on the east side of the station.

The commercial and service facilities provided along the street attracted a high volume of pedestrians, who usually have tendencies to conduct stationary activities, such as stopping to 

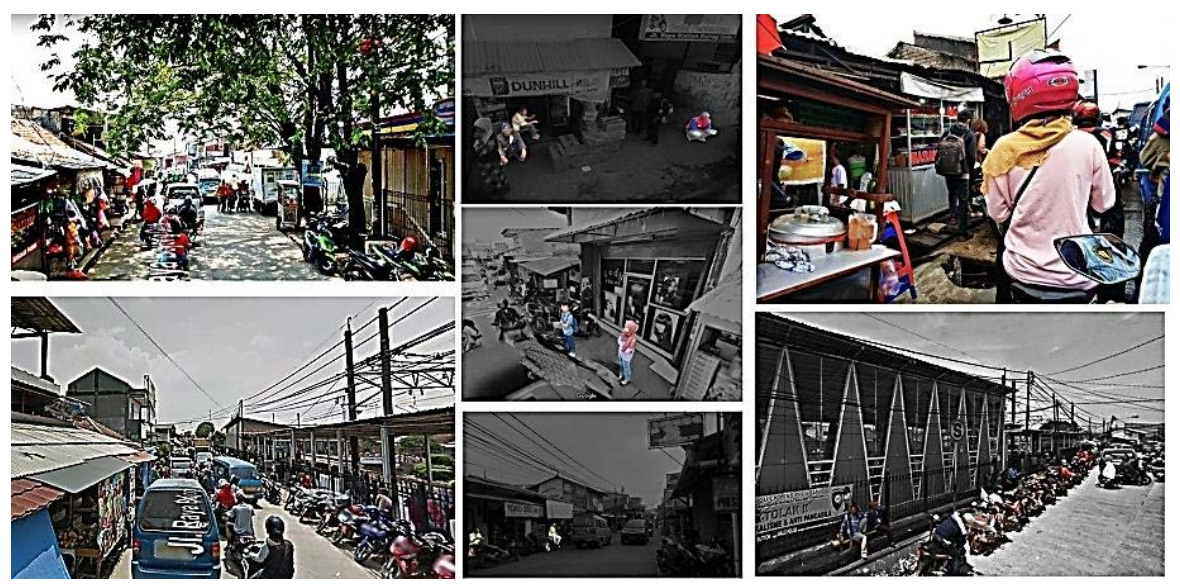

Figure 2: Surrounding Bojong Gede Station. (Source: Google Street View and Observation Survey by the Authors.)

buy foods offered by street vendors. As a result, pedestrians share the circulation space with the street vendors.

In this disorderly situation, which lacks proper comfort places for standing and sitting, people utilized any space they consider to be comfortable. We noticed standing activities occurred in any place when commuters wait for angkot or when street vendors have transactions with their customers. For the act of seating, we noticed some spots occur mainly at the shop verandahs and in front of blank walls, which form spatial markers. The former provided the shade, while the latter acted as a comfort zone. This kind of behavior, such as leaning against a wall, is commonly observed among ojek drivers, who are waiting for their customers. We rarely find the passersby sitting down, since proper seating spaces are not available along the street, with the exception of portable benches provided by the food vendors for their customers.

The corridors in front of Bojong Gede Station reflect a typical sight of the phenomenology of an instantly developing commercial strip located at the periphery of cities elsewhere in the world that expresses chaos and disorder. The density and infinite variety of sights, forms, colors, and materials, in addition to the constant crowding and general melee of vehicles and people add up to the turbulent visual and sensory experience. The street displays no clear differentiation, no exact boundaries and no sense of a center or a focal point. Visual coherence and aesthetics are totally absent, yet the seemingly disorganized quality of this traffic and commercial corridor attracts commuters to stop by and conduct various activities spontaneously.

\subsubsection{Universitas Pancasila Station}

The Pancasila University campus covers 12 hectares of land with the whole campus façade facing onto Lenteng Agung Street. The campus was designed with the deep setback to allow for green space and parking. The campus is bordered by the fence to barricade the campus site. The campus site and the Station are bordered by the arterial street of Lenteng Agung, which was basically designed for the movement of fast-moving vehicles or heavy traffic. The sidewalk is divided into three parts: 1) a green planted frontage zone in front of the campus 

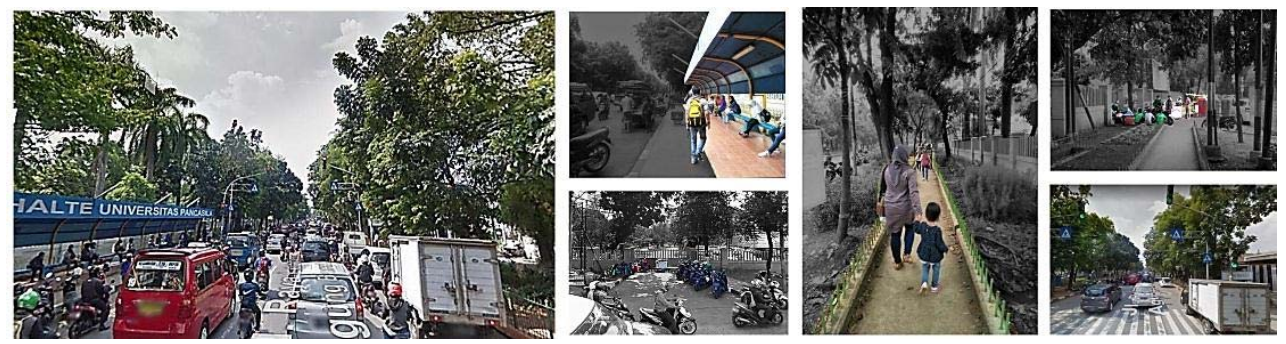

Figure 3: Surrounding Universitas Pancasila Station. (Source: Google Street View and Observation Survey by Authors.)

yard and parking areas; 2) a clear pedestrian pathway that continues all the way to the intersection; and 3) a green buffer zone to strictly protect the pedestrian zone from the vehicle zone. All urban elements, such as electricity poles and trees are neatly located in the buffer zone. In front of the main campus gate, there is a controlled traffic stop sign to allow the commuters and students to cross the street toward the station. Via the sidewalk and within an appropriate distance to the crossing location, a shaded bus shelter stands to shelter commuters who need to transfer from the train to bus feeder.

Obstructions, which appeared around the campus gate, are the result of commuters' responses while waiting for another connecting transportation mode. The most disturbing one is when GoJek drivers are waiting for the customers along the periphery of the street. A bunch of street vendors frequently occupied the pathway and they also cause obstruction since passersby stop to buy things. The only proper seating places for the commuters are provided at the bus shelter. Otherwise, there are no other places for the commuters to feel comfortable to sit around, with the view toward the street. Some commuters are squatting on the ground near the bus stop.

On the opposite of the station, the ambiance of the arterial street is completely different. The street has a boulevard to separate the fast-moving traffic from the slower local traffic. A stop sign is installed close to the station gate to allow the commuters to cross the street and to walk along an admittedly narrow pathway at the boulevard. As the transitional space, the boulevard gives a sense of safety for the commuters before crossing toward the neighborhood.

The primary objective of pedestrian planning concerning safety, security, convenience and continuity for the commuter around Universitas Pancasila Station is to support walking as an activity. Therefore, under all conditions, the pedestrian areas around the station only provide the commuters with enough spaces for utilitarian trips that take place throughout the year. However, optional places to socialize and interact could not be generated, as in the case of Bojong Gede Station.

\subsubsection{Duren Kalibata Station}

The existing premises surrounding Duren Kalibata Station fail to provide the solid-void relationship that holds public space together. Part of the problem is "POPs" (Privately Owned Public Spaces) that look public on the map but in reality, are not. The physical separation results from divisions of functions that create separated "islands" and massive clearance schemes for roads and freeways around the station. It is rarely possible to walk from a nearby "island" to another place, except by crossing the road amid high-speed vehicles. Using the footbridge means commuters have to take a long walk as the position of the pedestrian bridge 

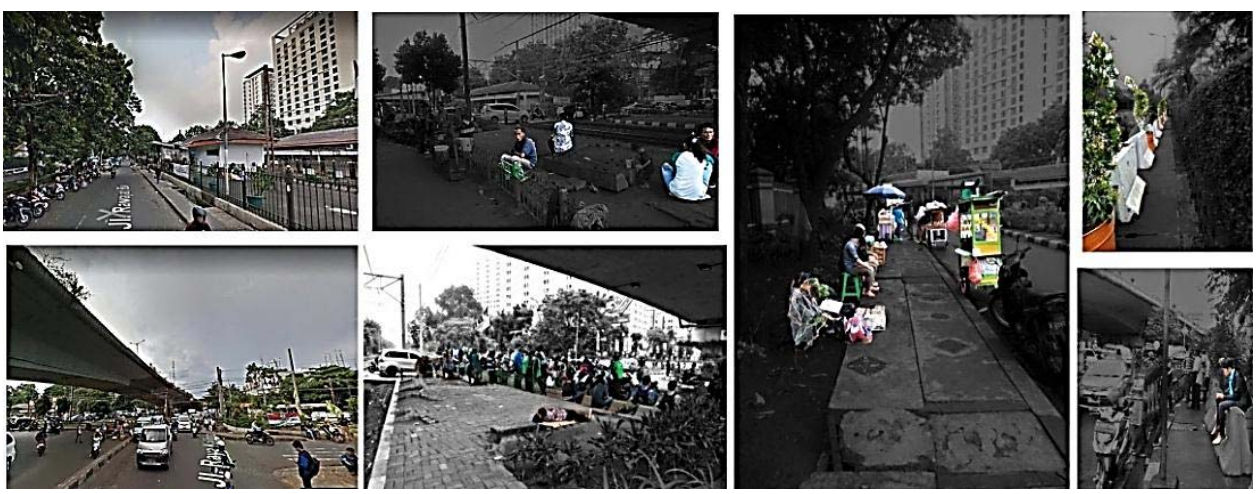

Figure 4: Surrounding Duren Kalibata Station. (Source: Google Street View and Observation Survey by Authors.)

is too far away. This typical situation happens everywhere, so jaywalking or crossing a roadway illegally is not an uncommon sight. In many places, the fences have been installed in the middle of the road to prevent jaywalking.

Observing the pedestrian area around the Duren Kalibata Station, we notice various obstructions that reduce the space of the walking area from the ideal width of $2.4 \mathrm{~m}-4.5 \mathrm{~m}$. The obstructions produced a minimal space of the pathway that pushes people to slow down, especially when they meet other people from the opposite direction. As commuters require mobility to run and to catch the train, some of them prefer to walk quickly on the street, rather in the designated pedestrian way.

When observing the behavior of commuters, we found that the absence of proper seating area triggers people to choose any random spot that they feel comfortable to lean against, such as a street barrier, unused rail pads or even squatting on the ground. The presence of a flyover creates a shady space underneath which is utilized by non-commuters such as street vendors, ojek drivers and street musicians. They take a rest and establish their bases for their informal enterprises. However, unlike the commuters, the traders prioritize the aspect of visibility and physical proximity to passersby. Rather than the sense of obstruction as a defense, this situation creates a high level of surveillance within the area.

Nevertheless, the level of surveillance of pedestrians is low in areas enclosed by passive frontages, such as blank walls and building fences. These passive urban elements act as barriers and inhibit activities because they block visual access to pedestrians. This situation leaves urban spaces dangerously vulnerable to a rise in crime and potential safety violations. Defensible space is another important factor whereby commuters feel secure in their surroundings at the station.

\subsubsection{Juanda Station}

Juanda Station is one of the biggest Commuter Line stations connected to the Bus Rapid Transit (BRT) System of Trans Jakarta. The station is elevated and connected with the pedestrian bridge directly to the Trans Jakarta transfer bus stop and Istiqlal Mosque. The interesting part is that commuters who get off the station platform will see dozens of off-line and online ojek drivers in front of the widely expanded station gate calling for passengers. After passing the gate, commuters walk along a pedestrian passageway under an overhead roof installed to protect the pedestrians from the direct sunlight and rain. 

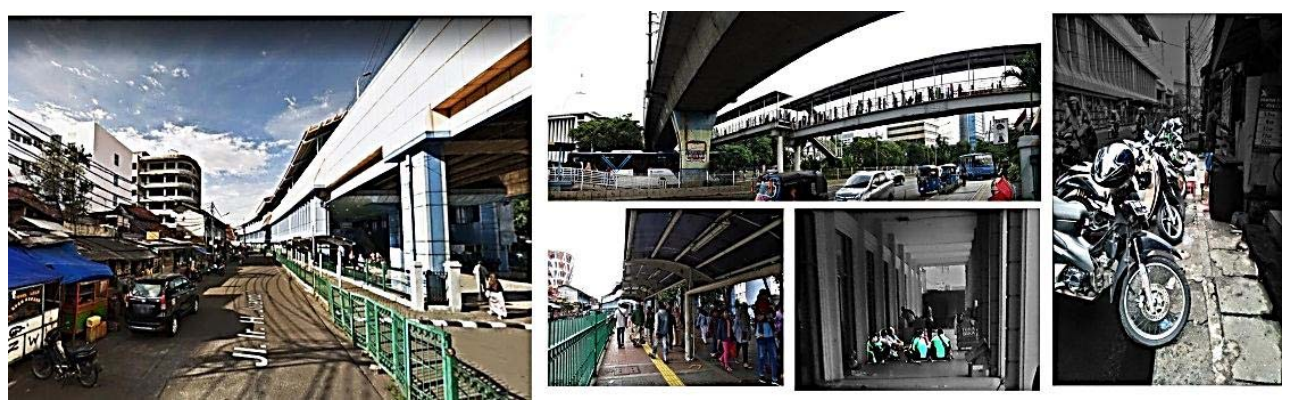

Figure 5: Surrounding Juanda Station. (Source: Google Street View and Observation Survey by Authors.)

Located in Central Jakarta, pedestrian arriving at the Juanda Station enjoyed the implementation of pedestrian planning programs led by Dinas Bina Marga (Department of Public Works). As a result, most of the pedestrian areas in Juanda are free from any obstructions. Pedestrian-friendly design features, such as wide sidewalks, tactile wayfinding, accessible ramps and S-railings to prevent the motorbike encroachment are visible.

However, crossing the road from the station to the commercial strip on the west side, commuters find entirely different conditions. There is no separation between the sidewalk and the street, forcing people to walk on the edge of the street. The motorbikes parked in front of the shops create an obstruction to the pedestrians. Commuters in cars must maneuver to avoid pedestrians, and this leads to the reduction in walking speed. During the peak hours on a hot day, the exhaust fumes and the humidity can make the walking experience terribly unpleasant.

Although important destinations such as $M O N A S$, the Istiqlal Mosque and the Cathedral are located at the vicinity of Juanda Station, to walk around to these locations is hard work to find shady places and for pedestrians to remain well-hydrated in the tropical heat. In the total absence of proper seating, we found commuters sit or lean wherever they can, especially if the place is shady and has a semi-enclosed environment. Many commuters use the wall for support and protection to lean against. The only intention to sit seems to take a rest, rather than waiting for a particular transportation mode or to enjoy the surrounding views. At the east side of the station, some people, mostly ojek drivers, lay down on the ground, below under-utilized building verandas, while waiting for customers.

\section{CONCLUSION}

Using the case studies presented herein, this paper draws lessons from examples of the surrounding stations as the important urban component in supporting the transit system in Greater Jakarta. The study revealed that although the four case studies have different physical context, in general the urban form exposed the compactness and diversity that opens up the possibility to adapt to the Railway-transit Oriented Development (ROD). Hence, the density (FAR) and land-use mixtures may not be carefully articulated or even partially defined in the context of RODs. Apparently, the areas around stations still have a long way to go to develop into high-quality and well-integrated urban design at the macro level.

The most difficult obstacle may appear in the case of the station in the buffer zone, particularly at Bojong Gede Station, since low FAR and lack of urban planning strategy would limit the growth around the station. As transit shapes urban development and land-use patterns affect travel demand [16], this complementary relationship calls for the strategic 
control on urban morphology and the urgency of modifying FARs surrounding the station. This type of analysis would be the basis for future research.

The revival of the Commuter Line encourages the new pattern of mobilization that attracts the commuters to access the stations and catch the train. The locations of all case studies are next to the trunk lines and connected to the street network that supports the commuters to continue their journeys using other transportation modes. Thus, in terms of location, all case studies met the principle requirement for Railway-transit Oriented Development. However, design factors dedicated to pedestrians, such as smooth and safe access to stations, amenities, and design mitigation of obstructions need serious improvement. Observation revealed that the area near the main station entrance is the prominent spot where the most circulation took place. For that reason, the area in front of the station's gate quickly changes in response to the constant presence of passersby. This situation met the defensible space principle [17] since the presence of people would increase the visual connectivity and surveillance level, while at the same time the presence also contributes to the liveliness of the area.

In the case of the behavioral patterns of commuters in the four stations' surroundings, the pattern of three major activities of walking, standing, and sitting differed based on the objective conditions of the existing spaces. Many obstructions had given impact how the commuters react to accommodate their needs for both the motion (movement) and the static (non-movement). Commuters have their own way of choosing a spot for doing activities. While walking, they tend to look for the shortest, direct, visible and less obstructed routes to reach the destination (the station). This requires an area with multiple intersections to increase the number of the route options as well as high visibility of the station. The study revealed that the pedestrian areas with many obstructions, such as street barriers and street vendors decreased the walking speed of the commuters.

The physical elements in the transit area create several new spots that are chosen by the commuters for their activities, but co-incidentally these spots emerged without any prior planning. This disarray worsened by the presence of other users, especially street vendors. The streets apparently display chaos and messiness. However, the bustling, layered, and chaos activities had "orders" that often visible and comprehensible only to their participants, thereby it opened the possibility to the subjugated by the notion of spatial and visual order recognized from institutional norms. The study revealed that informal spatial practices and ingrained cultural behaviors continued, notwithstanding the formal plan of urban upgrading and development, including surrounding stations.

Finally, as every transit trip begins and ends at the pedestrian level, we suggest that the current effort on major improvements of station building, facilities and train cabins should be complemented with an effort to improve facilities and amenities at the level of walking routes surrounding the stations. For the future research, we suggest the more in-depth analyses to determine the socio-cultural issues that can be translated into workable and feasible design recommendations for developing the surrounding stations that meet the culturally-specific behavior of local pedestrians.

\section{ACKNOWLEDGEMENTS}

This research/article's publication is supported by the United States Agency for International Development (USAID) through the Sustainable Higher Education Research Alliance (SHERA) Program for Universitas Indonesia's Scientific Modeling, Application, Research and Training for City-centered Innovation and Technology (SMART CITY) Project, Grant \#AID-497-A-1600004, Sub Grant \#IIE-00000078-UI-1). 


\section{REFERENCES}

[1] Montgomery, C., The Happy City. Farrar, Straus and Giroux: New York, p. 37, 2013.

[2] Online. www.pps.org. Accessed on: 26 Apr. 2017.

[3] Kulash, W., The third motor age. Place Journal, 10(2), pp. 42-49, 1996.

[4] Caïd, N., Crist, P., Gilbert, R. \& Wiederkehr, P., Environmentally sustainable transport: concept, goal and strategy - the OECD's EST project. Proceedings of the Institution of Civil Engineers-Transport, 153(4), pp. 219-226, 2002. DOI: 10.1680/tran.2002.153.4.219.

[5] Hayash, Y., Doi, K., Yagishita, M. \& Kuwata, M., Urban transport sustainability: asian trends, problems and policy practices. European Journal of Transport and Infrastructure Research (EJTIR), 4(1), pp. 27-45, 2004.

[6] Project for the Study on Jabodetabek Public Transportation Policy Implementation Strategy in the Republic of Indonesia, Indonesia (JAPTraPIS). http://open_jicareport.jica.go.jp/pdf/12079000_01.pdf. Accessed on: 18 May 2018.

[7] Pardosi, T. et.al., Statistik Transportasi DKI Jakarta 2016 (Transportation Statistic of DKI Jakarta), BPS Provinsi DKI Jakarta: Jakarta, 2016.

[8] Online: www.beritasatu.com/jakarta/450800-bptj-targetkan-pengguna-angkutanumum-capai-60-di-2029.html. Accessed on: 16 Mar. 2018.

[9] Rekor Penumpang KRL 'Commuter Line' Capai 1 Juta Orang per Hari, megapolitan.kompas.com/read/2017/06/20/20343781/rekor.penumpang.krl.commute r.line.capai.1.juta.orang.per.hari. Accessed on: 13 Jan. 2018.

[10] Mateo-Babiano, I. \& Ieda, H., Street space sustainability in Asia: the role of the Asian pedestrian and street culture. Journal of the Eastern Asia Society of Transportation Studies, 7, 2007, pp. 1815-1930.

[11] The spatial organization of cities: Deliberate outcome or unforeseen consequence? Online.

http://alainbertaud.com/images/AB_The_spatial_organization_of_cities_Version_3.p df. Accessed on: 21 Apr. 2018.

[12] Suzuki, H., Cercero, R. \& Iuchi, K., Transforming Cities with Transit, The World Bank: Washington, 2013.

[13] Gutman, R., (ed.), People and Building, Transaction Publisher: New York, 2009.

[14] Matan, A. \& Newman, P., People Cities: The Life and Legacy of Jan Gehl, Island Press: Washington DC, 2016.

[15] Ellisa, E., Coping with crowding in high-density Kampung housing of Jakarta. International Journal of Architectural Research, 10(1), pp. 194-212, 2016. DOI: 10.26687/archnet-ijar.v10i1.790.

[16] Ewing, R. \& Cervero, R., Travel and the built environment. Journal of the American Planning Association, 76(3), pp. 265-294, 2010.

[17] Newman, O., Creating Defensible Space, US Department of Housing and Urban Development Office of Policy Department and Research, 1996. 